\title{
Neuroprotective Role of Dopamine Against Hippocampal Cell Death
}

\author{
Yuri Bozzi, Daniela Vallone, and Emiliana Borrelli \\ Institut de Génétique et de Biologie Moléculaire et Cellulaire, Centre National de la Recherche Scientifique/Institut National \\ de la Santé et de la Recherche Médicale/Université Louis Pasteur, 67404 Illkirch Cedex, Communauté Urbaine de \\ Strasbourg, France
}

\begin{abstract}
Glutamate excitotoxicity plays a key role in the induction of neuronal cell death occurring in many neuropathologies, including epilepsy. Systemic administration of the glutamatergic agonist kainic acid (KA) is a well characterized model to study epilepsy-induced brain damage. KA-evoked seizures in mice result in hippocampal cell death, with the exception of some strains that are resistant to KA excitotoxicity. Little is known about the factors that prevent epilepsy-related neurodegeneration. Here we show that dopamine has such a function through the activation of the D2 receptor (D2R). D2R gene inactivation confers susceptibility to KA excitotoxicity in two mouse strains known to be resistant to KA-induced neurodegeneration. $\mathrm{D} 2 \mathrm{R}-/$ - mice develop seizures when administered KA doses
\end{abstract}

Dysfunctions of glutamatergic neurotransmission are thought to play a key role in the induction of neuronal cell death occurring after brain trauma and in neurological disorders (Choi, 1988; Coyle and Puttfarcken, 1993; Meldrum 1995). Sustained activation of glutamate receptor (GluR) signaling pathways by extensive release of glutamate in susceptible areas leads to neuronal damage through apoptosis (Choi, 1994; Pollard et al., 1994).

Epilepsy is one pathological condition characterized by localized bursts of electrical overactivity (seizures) in the cerebral hemispheres. Outbursts of electrical activity, commonly observed in cortical and subcortical areas, can result in extensive neuronal cell death in different brain regions. A glutamate-dopamine interaction has been proposed to explain individual susceptibility to epilepsy, based on the effect of antipsychotics (i.e., dopaminergic D2-like antagonists) (Starr, 1996). These compounds, despite their positive effects in the treatment of disorders such as schizophrenia, have been shown to lower the seizure threshold in epileptic patients or even to promote seizures in patients with no previous history of the disease. Conversely, seizure inhibition has been observed in patients administered antiparkinsonian drugs such as pergolide and bromocriptine, both D2-like agonists (Starr, 1996). The limbic system is crucially involved in the dopaminergic control of epileptic seizures. Indeed, limbic areas of the brain receive dopaminergic innervation (Verney et al., 1985) and express different types of

\footnotetext{
Received June 23, 2000; revised Aug. 24, 2000; accepted Sept. 6, 2000.

This work was supported by grants from the Institut National de la Santé et de la Recherche Médicale, Centre National de la Recherche Scientifique, Hôpital Universitaire de Strasbourg, and Association de la Recherche sur le Cancer to E.B. Y.B. was supported by fellowships from the Ligue Nationale contre le Cancer and Fondation pour la Recherche Médicale. D.V. was supported by a European Community fellowship. We thank Y. Ben-Ari, H. Gozlan, P. Sassone-Corsi, N. Foulkes, and all the members of the laboratory for discussions. We thank V. Giroult, B. Boulay, and J.-M. Lafontaine for technical help.

Correspondence should be addressed to Emiliana Borrelli, Institut de Génétique et de Biologie Moléculaire et Cellulaire, Centre National de la Recherche Scientifique/ Institut National de la Santé et de la Recherche Médicale/Université Louis Pasteur, BP163, 67404 Illkirch Cedex, Communauté Urbaine de Strasbourg, France. E-mail: eb@igbmc.u-strasbg.fr.

Dr. Bozzi's present address: Neurobiology Laboratory, Scuola Normale Superiore, Consiglio Nazionale delle Ricerche, Institute of Neurophysiology, Via Alfieri 1, 56010 Ghezzano, Pisa, Italy. E-mail: yuri@in.pi.cnr.it.

Copyright (C) 2000 Society for Neuroscience $0270-6474 / 00 / 208643-07 \$ 15.00 / 0$
}

that are not epileptogenic for wild-type (WT) littermates. The spatiotemporal pattern of c-fos and c-jun mRNA induction well correlates with the occurrence of seizures in D2R-/- mice. Moreover, KA-induced seizures result in extensive hippocampal cell death in D2R-/- but not WT mice. In KA-treated D2R-/mice, hippocampal neurons die by apoptosis, as indicated by the presence of fragmented DNA and the induction of the proapoptotic protein BAX. These results reveal a central role of D2Rs in the inhibitory control of glutamate neurotransmission and excitotoxicity.

Key words: epilepsy; excitotoxicity; apoptosis; dopamine D2 receptors; glutamate receptors; kainic acid dopamine receptors (Jackson and Westlind-Danielsson, 1994). Among these, D1 and D2 receptors seem to play opposite roles in regulating the threshold for seizures (Starr, 1993).

We investigated the effect of glutamate-induced seizures and neurotoxicity in dopamine D2 receptor knock-out (D2R-/-) mice (Baik et al., 1995). Glutamate-induced seizures were evoked by the systemic administration of kainic acid (KA), a potent agonist of the AMPA/kainate class of glutamate receptors (Hollmann and Heinemann, 1994). Systemic administration of KA in rodents has been widely used and characterized as a model to study the behavioral, anatomical, cellular, and genetic bases of glutamate neurotoxicity (Schauwecker and Steward, 1997, and references therein). KA treatment determines a well defined pattern of activation of specific brain areas, which is correlated with the appearance of limbic seizures (Lothman and Collins, 1981; Lothman et al., 1981; Willoughby et al., 1997). KA-evoked seizures result in neuronal cell loss in restricted subfields of the hippocampal formation (Ben-Ari, 1985), with the exception of some mouse strains that are resistant to KA excitotoxicity (Schauwecker and Steward, 1997).

In the present study, we show that the absence of D2R in two mouse strains known to be resistant to KA-induced neurodegeneration (C57BL/6 and mixed 129/Sv $\times$ C57BL/6) $($ Schauwecker and Steward, 1997) confers susceptibility to KA excitotoxicity. D2R - / - mice develop seizures when administered KA doses that are not epileptogenic for wild-type (WT) littermates. Moreover, KA-induced seizures result in extensive hippocampal cell death in D2R-/- but not WT mice. These results suggest a neuroprotective role of dopamine D2 receptors against glutamate-induced excitotoxicity.

\section{MATERIALS AND METHODS}

Animals. D2R - / - mice were generated previously in our laboratory (Baik et al., 1995). All mice used for this study were male and female $F_{2}$ hybrids (C57BL/6 $\times 129 / \mathrm{Sv}$ mixed background) obtained from heterozygote intermatings. For the evaluation of KA-induced hippocampal cell death, we also used a congenic C57BL/6 strain carrying the mutated D2R allele. This strain was established by backcrossing $\mathrm{D} 2 \mathrm{R}+/-$ mice $\left(\mathrm{F}_{2}\right.$ hybrids) to C57BL/6 mice for five generations (Silva et al., 1997). After the fifth backcross, the colony was expanded by inbreeding pairs of nonsibling $+/-$ male and female mice. Animals were housed in a $12 \mathrm{hr}$ light/dark cycle with food and water available ad libitum. Experiments were conducted in conformity with the European Communities Council Directive of November 24, 1986 (86/609/EEC). 
Behavioral analyses. Adult ( $\mathrm{F}_{2}$ hybrids; 3- to 5-month-old; weight, 20-30 gm) $\mathrm{D} 2 \mathrm{R}+/+, \mathrm{D} 2 \mathrm{R}+/-, \mathrm{D} 2 \mathrm{R}-/-, 129 / \mathrm{Sv}$, and C57BL/6 mice of both sexes were used ( $n=10$ mice per genotype and treatment group). In all of the experiments, the experimenter was blind to the genotype and treatment of the animals. KA (Sigma, St. Louis, MO) was dissolved in saline and administered intraperitoneally at 10,20 , and $35 \mathrm{mg} / \mathrm{kg}$ body weight. Saline-injected animals were used as controls. Seizure severity was determined according to a previously defined rating scale (Schauwecker and Steward, 1997): stage 0, normal behavior; stage 1, immobility; stage 2, forelimb and/or tail extension, rigid posture; stage 3, repetitive movements, head bobbing; stage 4, rearing and falling; stage 5, continuous rearing and falling; stage 6 , severe whole-body convulsions; and stage 7 , death. For each animal, the rating scale value was scored every $20 \mathrm{~min}$ for a maximum of $2 \mathrm{hr}$. The maximum rating scale values reached by each animal over the whole observation period were used to calculate the rating scale value $( \pm$ SEM $)$ for each treatment group. Statistical analysis was performed by Mann-Whitney $U$ test. Data from male and female animals were initially analyzed separately. Because no difference in seizure rating scale values was observed between the two genders in each genotype and treatment group, data were pooled together.

Receptor autoradiography. Brain cryostat sections $(10 \mu \mathrm{m})$ from WT and D2R-/- mice (3- to 5-month-old; $n=3$ per genotype) were used for autoradiographic binding. D2R binding was performed with ${ }^{125} \mathrm{I}$ iodosulpride (2000 Ci/mmol; Amersham Pharmacia Biotech, Little Chalfont, UK) as described previously (Martres et al., 1985). For high-affinity kainate binding (Berger and Ben-Ari, 1983), sections were preincubated for $15 \mathrm{~min}$ at $37^{\circ} \mathrm{C}$ in $50 \mathrm{~mm}$ Tris-acetate buffer and incubated for $1 \mathrm{hr}$ at $4^{\circ} \mathrm{C}$ with $20 \mathrm{~nm}$ vinilydene $-{ }^{3} \mathrm{H}$-kainic acid $(30-60 \mathrm{Ci} / \mathrm{mmol}$; NEN, Boston, MA). Low-affinity binding sites were displaced by incubating the sections for $2 \mathrm{~min}$ at $4^{\circ} \mathrm{C}$ in the presence of $10 \mu \mathrm{M}$ cold kainic acid in the same buffer. Sections were washed in ice-cold buffer, rinsed in $\mathrm{H}_{2} \mathrm{O}$, dried, and exposed for 1-3 months to Kodak Biomax autoradiographic films (Eastman Kodak, Rochester, NY). Pictures were taken directly from film autoradiograms.

Immunoblotting. Hippocampi from $\mathrm{WT}$ and $\mathrm{D} 2 \mathrm{R}-/-$ mice (3- to 5 -month-old; $n=3$ per genotype) were rapidly dissected, frozen, and homogenized in $500 \mu \mathrm{l}$ of lysis buffer $(50 \mathrm{~mm}$ Tris, $\mathrm{pH} 7.5,150 \mathrm{~mm} \mathrm{NaCl}$ $1 \mathrm{~mm}$ EDTA, pH 8.0, $1 \%$ Triton $\mathrm{X}-100,10 \%$ glycerol, $0.1 \%$ SDS, $1 \mathrm{~mm}$ PMSF, $1 \mathrm{mg} / \mathrm{ml}$ aprotinin, $1 \mathrm{mg} / \mathrm{ml}$ leupeptin, $1 \mathrm{~mm}$ sodium orthovanadate and $50 \mathrm{~mm} \mathrm{NaF})$. Same amounts $(20 \mu \mathrm{g} / \mathrm{sample})$ of hippocampal total protein were resolved by SDS-PAGE and probed with GluR1, GluR2/3, GluR6/7, and KA2 polyclonal antibodies (Upstate Biotechnology, Lake Placid, NY). Signals were revealed by enhanced chemiluminescence (ECL; Amersham Pharmacia Biotech) and quantified by a Bio-Rad (Hercules, CA) GS-700 Imaging Densitometer.

In situ hybridization. WT and D2R-/- mice (3- to 5-month-old; $n=3$ per genotype and treatment group) were killed at different times after saline or KA injection $(1,3,6$, and $12 \mathrm{hr})$. Brains were rapidly removed and frozen on dry ice. In situ hybridizations on cryostat sections were performed with ${ }^{35}$ S-labeled antisense c-fos (Halazonetis et al., 1988) and c-jun (Mellström et al. 1991) riboprobes as described previously (Bozzi and Borrelli, 1999). After hybridization, slides were exposed for 1-4 d at room temperature to Kodak BIOMAX x-ray films. Pictures were taken directly from film autoradiograms. The specificity of the results was confirmed by the use of sense riboprobes, which gave no detectable signal (data not shown). The extension and subdivision of brain areas was determined according to Franklin and Paxinos (1997).

Immunohistochemistry, terminal deoxynucleotidyl transferase-mediated biotinylated UTP nick end labeling, and histology. In situ terminal deoxynucleotidyl transferase-mediated biotinylated UTP nick end labeling (TUNEL) of fragmented DNA and BAX immunohistochemistry were performed on brain cryostat sections from male and female WT and $\mathrm{D} 2 \mathrm{R}-/-$ mice ( $\mathrm{F}_{2}$ hybrids; 3- to 5-month-old) killed $16 \mathrm{hr}$ after KA injection $(20$ or $35 \mathrm{mg} / \mathrm{kg}$, i.p.; $n=5$ animals per genotype and treatment group). TUNEL staining was detected by the ApopTag kit (Oncor). After diaminobenzidine (DAB) reaction, sections were counterstained with methyl green. For BAX immunostaining, adjacent sections were fixed in acetone/methanol (1:1 mixture), incubated for $1 \mathrm{hr}$ in blocking solution (5\% normal goat serum, $0.05 \%$ Tween 20 , and $1 \times$ PBS) and probed overnight at $4^{\circ} \mathrm{C}$ with an anti-BAX polyclonal antibody (1:100 dilution in blocking solution; Santa Cruz Biotechnology, Santa Cruz, CA). Sections were then washed, and signal was revealed with a fluorescent (Cy3conjugated) goat anti-rabbit secondary antibody (Jackson ImmunoResearch, West Grove, PA). Cresyl violet staining (Nissl coloration) and glia fibrillary acidic protein (GFAP) immunohistochemistry were performed on paraffin sections from $\mathrm{WT}$ and $\mathrm{D} 2 \mathrm{R}-/-$ mice $\left(\mathrm{F}_{2}\right.$ hybrids; 3- to 5 -month-old) killed $5 \mathrm{~d}$ after KA injection ( 20 or $35 \mathrm{mg} / \mathrm{kg}$, i.p.; $n=5$ per genotype and treatment group). GFAP immunohistochemistry was performed using an anti-GFAP polyclonal antibody (1:800 dilution in blocking solution; Sigma), followed by incubation with a Cy3-conjugated secondary antibody (Jackson ImmunoResearch).

Statistical analysis of TUNEL staining and morphological evaluation of hippocampal cell damage. For the quantification of TUNEL experiments, five animals of each genotype and treatment were used. For each animal, five different coronal sections were collected (one every $150 \mu \mathrm{m}$ ), spanning through the whole dorsal hippocampus. After TUNEL reaction followed by histological counterstaining (see above), sections were observed at $10 \times$
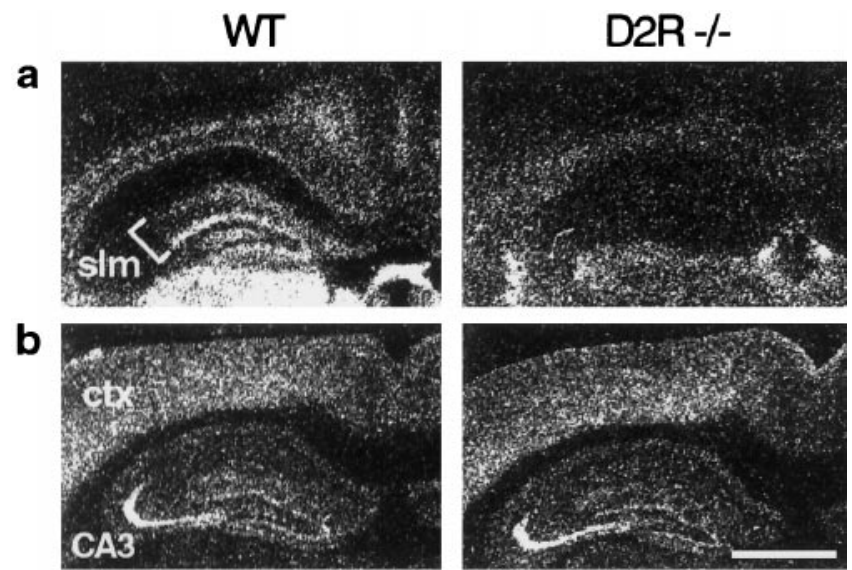

C

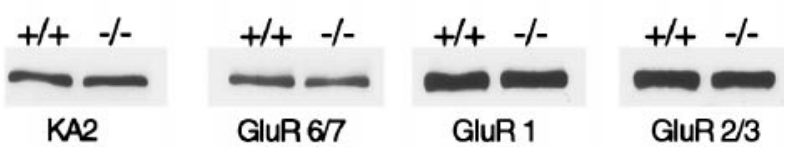

Expression of D2 and glutamate receptors in $\mathrm{WT}$ and D2R $-/-$ mice, $a, \mathrm{D} 2 \mathrm{R}$ binding sites in the hippocampus of $\mathrm{WT}$ and $\mathrm{D} 2 \mathrm{R}-1-$ mice. $b$, High-affinity KA binding sites in the cerebral cortex and hippocampus of WT and D2R - / - mice. ctx, Cerebral cortex; $C A 3$, CA3 hippocampal subfield; $D G$, dentate gyrus; slm, stratum lacunosum moleculare. Scale bar, $1.3 \mathrm{~mm}$. $c$, Immunoblotting of glutamate receptor subunits (as indicated) on protein extracts from WT $(+/+)$ and D2R $-/-(-/-)$ hippocampi.

primary magnification under a light microscope. For each section, two measurements were taken (one for each side) by counting the TUNELpositive CA3 cells present in a $400 \times 400 \mu \mathrm{m}$ sample area. The extension of this area was appropriately chosen to contain the whole CA3 region of each side. Only those CA3 cells that exhibited a DAB nuclear staining were considered TUNEL-positive. The different measurements taken from each animal were initially used to calculate the average number of TUNEL-positive CA3 cells per area for each animal. The average values per animal ( $n=5$ per genotype and treatment) were then used for statistical analysis. Mann-Whitney $U$ test was used to compare the results obtained in the different genotypes and treatment groups. Results are shown as the mean \pm SEM value of TUNEL-positive CA3 cells per area.

To evaluate the degree of KA-induced hippocampal cell damage, Nisslstained sections from five animals of each genotype and treatment were used. Sections from each mouse were assigned the following score according to Morrison et al. (1996): little damage, occasional single-cell degeneration in CA3 area; mild damage, small area with degenerated CA3 pyramidal cells; and severe damage, extended area of neuronal degeneration, neuronal cell loss and tissue sclerosis, frequently including both dorsal and ventral hippocampal CA3 regions.

No difference in TUNEL or Nissl staining was observed between male and female mice of the same genotype. Therefore, data were pooled together, and all of the results shown in this study include both genders.

\section{RESULTS}

The distribution of D2R binding sites in the brain of WT and $\mathrm{D} 2 \mathrm{R}-/-$ mice was evaluated by autoradiographic in situ binding with ${ }^{125}$ I-iodosulpiride on brain sections. D2Rs were present in the stratum lacunosum moleculare of the dorsal hippocampus (CA1 and CA3 regions), as well as in the hilum of dentate gyrus in WT mice (Fig. 1a) (Martres et al., 1985; Bouthenet et al., 1987). As expected, D2R binding sites were absent in the D2R-/- hippocampus (Fig. 1a). Persistent ${ }^{125}$ I-iodosulpiride binding was detected in the habenula of D2R-/- mice, likely because of D3 dopamine receptors present in this area (Bouthenet et al., 1991). Previous studies from our laboratory demonstrated that there is no evidence for any residual $\mathrm{D} 2 \mathrm{R}$ binding in the $\mathrm{D} 2 \mathrm{R}-/-$ mouse brain (Baik et al., 1995). Glutamate receptor channels of the AMPA/KA subclass are mainly expressed in limbic areas and are involved in epileptogenesis (Dingledine et al., 1990; Seeburg, 1993; Hollmann and Heinemann, 1994). Autoradiographic in situ binding with ${ }^{3} \mathrm{H}-\mathrm{KA}$ revealed a comparable pattern of KA high-affinity binding sites in the hippocampus (Fig. 1b), cerebral cortex (Fig. 1b), and striatum (data not shown) of $\mathrm{WT}$ and $\mathrm{D} 2 \mathrm{R}-/-$ mice. Immunoblotting analysis also revealed comparable levels of KA (KA2 


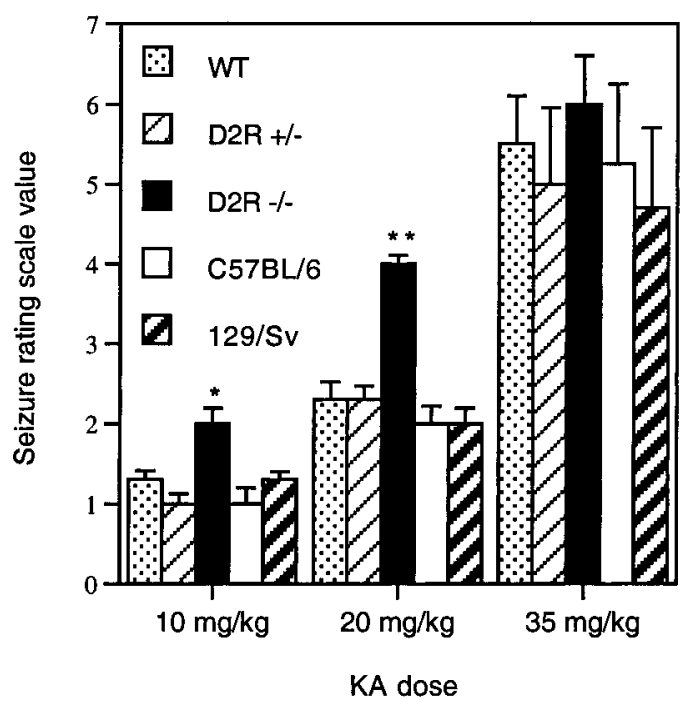

Figure 2. Severity of KA-induced seizures in WT, D2R+/-, D2R-/-, C57BL/6, and 129/Sv mice. Dose-response effect of KA treatments in the different genotypes tested, as indicated $(n=10$ mice per genotype). Columns represent the maximum seizure rating scale value scored by each genotype over a period of $2 \mathrm{hr}$ after KA administration. Data are expressed as mean \pm SEM. * $p<0.05$; ${ }^{*} p<0.01$; Mann-Whitney $U$ test between $\mathrm{D} 2 \mathrm{R}-1-$ and each of the other genotypes.

and GluR6/7) and AMPA (GluR1 and GluR2/3) receptor subunits in the hippocampus of $\mathrm{WT}$ and $\mathrm{D} 2 \mathrm{R}-/-$ mice (Fig. $1 c$ ).

The behavioral response of WT, D2R $+/-$ and $\mathrm{D} 2 \mathrm{R}-/-$ male and female mice to increasing doses of the epileptogenic drug KA $(10,20$, and $35 \mathrm{mg} / \mathrm{kg}$, i.p.) was then evaluated over a period of 2 hr after administration. KA treatment had a clear dose-dependent effect in all genotypes. At a dose of $10 \mathrm{mg} / \mathrm{kg}$, WT and D2R+/animals remained immobile, whereas $\mathrm{D} 2 \mathrm{R}-/-$ showed preconvulsive behaviors (rigid posture, tail stiffening, and forelimb extension) (Fig. 2). At $20 \mathrm{mg} / \mathrm{kg}$, D2R - / - mice showed clear symptoms of limbic epileptic activity (repeated episodes of rearing with forelimb clonus, alternating with rigid posture and head bobbing) (Fig. 2), whereas WT and D2R+/- mice exhibited only preconvulsive signs (Fig. 2). Finally, the high dose of $35 \mathrm{mg} / \mathrm{kg}$ induced repeated limbic seizures of the same severity in the three genotypes during the whole period of observation (Fig. 2). In each treatment group, no difference was observed between male and female mice of the same genotype. Saline-treated animals of all genotypes showed no sign of epileptic activity during the entire period of observation (data not shown). In parallel with these experiments, KA effects were also evaluated in 129/Sv and C57BL/6 mice, the two strains of mice from which $\mathrm{D} 2 \mathrm{R}-/-$ mutants are derived (Baik et al., 1995). Both of these strains exhibited a similar behavioral KA dose-response profile as D2R+/- and WT siblings (Fig. 2).

We next used immediate early gene (IEG) induction (Morgan and Curran, 1991; Willoughby et al., 1997) to study the spatiotemporal pattern of neuronal activation in WT and $\mathrm{D} 2 \mathrm{R}-/-$ mice after $20 \mathrm{mg} / \mathrm{kg} \mathrm{KA}$ treatment. One hour after KA injection, a strong c-fos mRNA induction was detected in the hippocampus and cerebral cortex in both genotypes compared with saline-treated mice (Fig. $3 a$ ). Three hours after KA administration, a strong and widespread c-fos expression was detected throughout the entire brain in D2R -/ - mice (Fig. 3a), whereas WT animals showed a reduced labeling, restricted mainly to the hippocampus. A sustained c-fos expression was still present in the hippocampus and cerebral cortex in D2R $-/-$ mice $6 \mathrm{hr}$ after KA treatment (Fig. $3 a$ ), whereas no labeling was detected in WT siblings (except a weak labeling in scattered cells of the hippocampus and cerebral cortex) (Fig. 3a). A robust c-jun induction was also observed in the dentate gyrus, CA1, and CA3 regions $6 \mathrm{hr}$ after $20 \mathrm{mg} / \mathrm{kg} \mathrm{KA}$ administration a

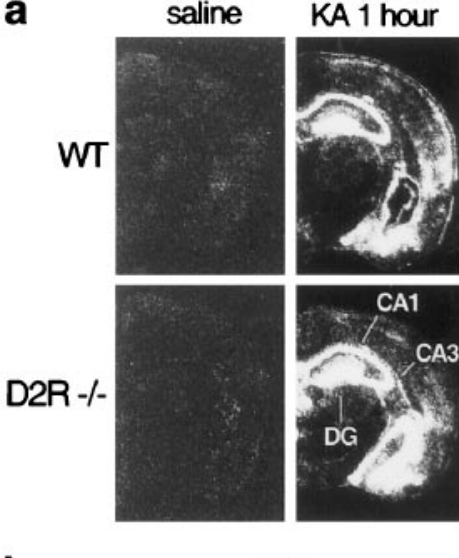

b

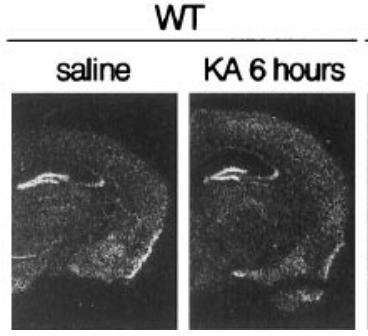

KA 3 hours
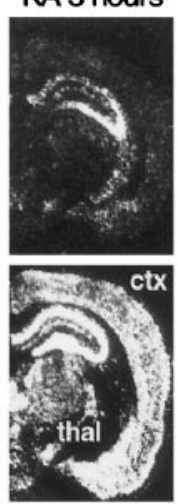

D2R - -

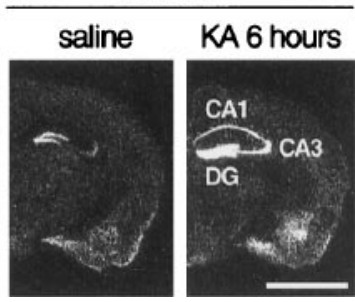

Figure 3. Spatiotemporal pattern of IEGs induction in the brain of WT and D2R $-/-$ mice treated with $20 \mathrm{mg} / \mathrm{kg} \mathrm{KA}$. c-fos $(a)$ and c-jun $(b)$ mRNA in situ hybridizations. Genotypes, treatments, and relevant brain areas are as indicated. $C A 1, C A 3$, Pyramidal cell layers of the hippocampus; ctx, cerebral cortex; $D G$, dentate gyrus; thal, thalamus. Scale bars, $1.8 \mathrm{~mm}$.

in D2R -/ - but not WT animals (Fig. 3b). Thus, IEG expression correlates with the occurrence of limbic seizures in mutant mice.

c-jun induction is considered as one of the first steps in the execution of neuronal programmed cell death (Estus et al., 1994). Thus, we investigated two well documented parameters of this process: DNA fragmentation (Pollard et al., 1994) and upregulation of the proapoptotic protein BAX (Gillardon et al., 1995; Krajewski et al., 1995; Deckwerth et al., 1996). WT and D2R-/mice of both sexes were killed $16 \mathrm{hr}$ after 20 or $35 \mathrm{mg} / \mathrm{kg}$ KA administration. This time point was chosen according to previous studies, which investigated the time course of KA-induced hippocampal programmed cell death (Sakhi et al., 1994). TUNEL staining of brain sections revealed the presence of fragmented DNA in CA3 cells in D2R-/- but not WT mice (Figs. $4 a, b, 5$ ). In $\mathrm{D} 2 \mathrm{R}-/-$ mice, the number of TUNEL-positive cells was significantly increased in a dose-dependent manner (Fig. 5). In each treatment group, no difference was observed between male and female mice of the same genotype. A strong BAX immunoreactivity was also observed in the CA3 region of $\mathrm{D} 2 \mathrm{R}-/-$ but not WT animals $16 \mathrm{hr}$ after KA (20 and $35 \mathrm{mg} / \mathrm{kg}$ ) administration (Fig. 4c). Basal levels of BAX protein were almost undetectable and did not differ in the hippocampus of WT and D2R-/- mice (data not shown). In D2R-/- mice, the extension of BAX labeling was larger than that of TUNEL staining (Fig. 4, compare $b, c$ ), suggesting that a residual number of BAX-positive CA3 neurons are not yet degenerated $16 \mathrm{hr}$ after KA treatment. Nissl coloration of brain sections from animals killed 5 d after KA (20 and $35 \mathrm{mg} / \mathrm{kg}$ ) injection revealed a clear breach of staining in the CA3 subfield of $\mathrm{D} 2 \mathrm{R}-/-$ but not WT mice (Fig. $6 a, b$ ). Cell loss in $\mathrm{D} 2 \mathrm{R}-/-$ mice was present only in the CA3 subfield but not in other regions of the hippocampus (Figs. 4, 6). The extension of tissue damage in the CA3 subfield, as revealed by the sclerotic zone and by the presence of densely stained pyknotic cells outside this zone (Fig. $6 b$ and data not shown), was larger than the TUNEL-positive region observed $16 \mathrm{hr}$ after KA treatment (compare Figs. 4b, 6b). Consistent with brain tissue damage, an extensive gliosis was observed in the CA3 subfield of D2R $-/-$ mice by GFAP immunohistochemistry (Dusart et al., 1991) (Fig. 6c). Morphological analysis of Nissl- 

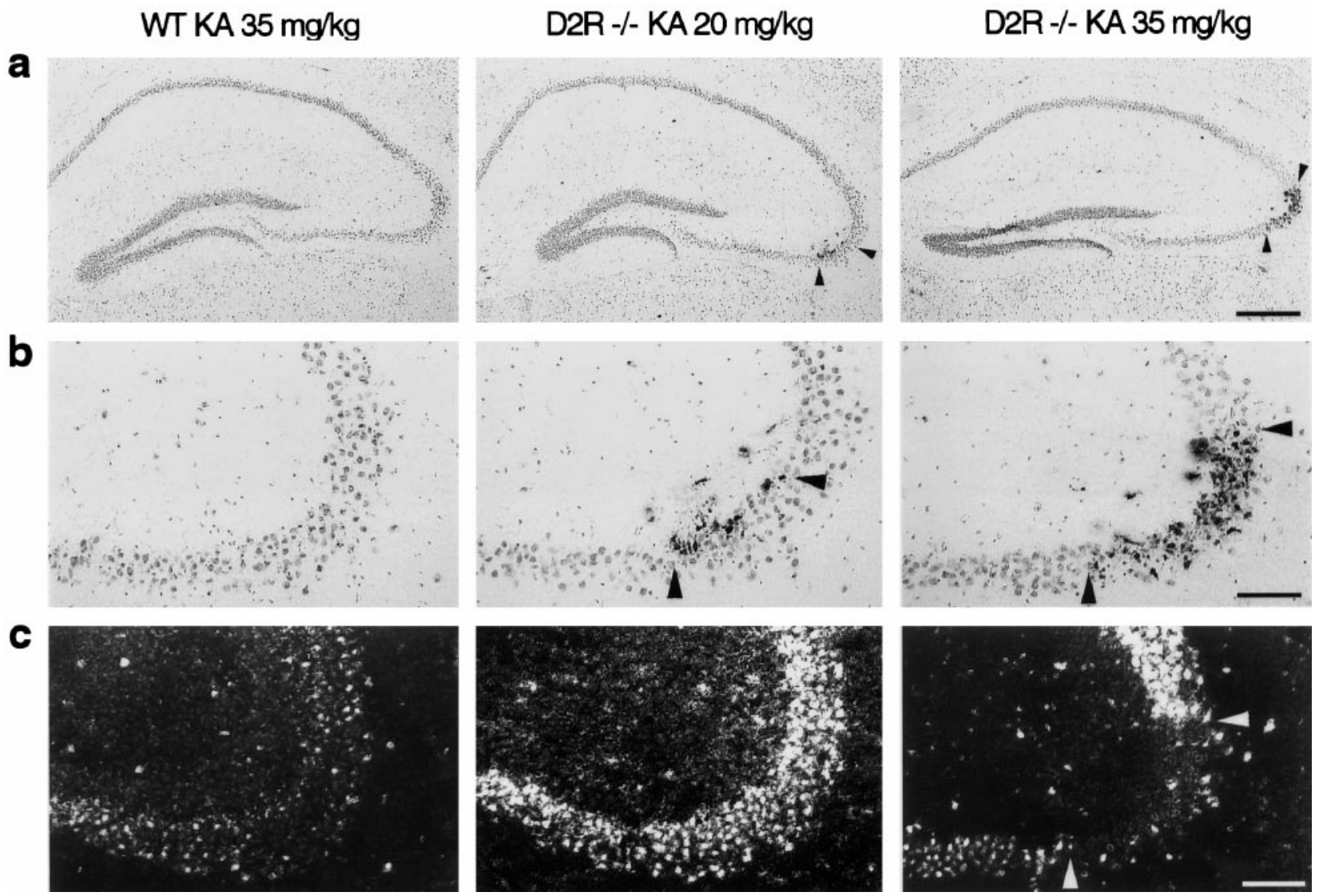

Figure 4. KA-evoked seizures induce CA3 neuron apoptosis in D2R-/- but not WT mice. $a$, TUNEL staining of the whole dorsal hippocampus from mice killed $16 \mathrm{hr}$ after KA treatment. $b$, High-power magnifications taken from the same sections shown in $a$. Arrowheads in $a$ and $b$ indicate the extension of TUNEL in a restricted part of the CA3 region. $c$, BAX immunoreactivity in CA3 pyramidal cells of WT and D2R - /- mice killed 16 hr after KA treatment. The absence of BAX labeling in the CA3 region of D2R $-1-$ mice treated with $35 \mathrm{mg} / \mathrm{kg}$ KA (between arrowheads) corresponds to the region containing TUNEL-positive cells. Genotypes and treatments are as indicated. Scale bars: $a, 300 \mu \mathrm{m} ; b, c, 70 \mu \mathrm{m}$.

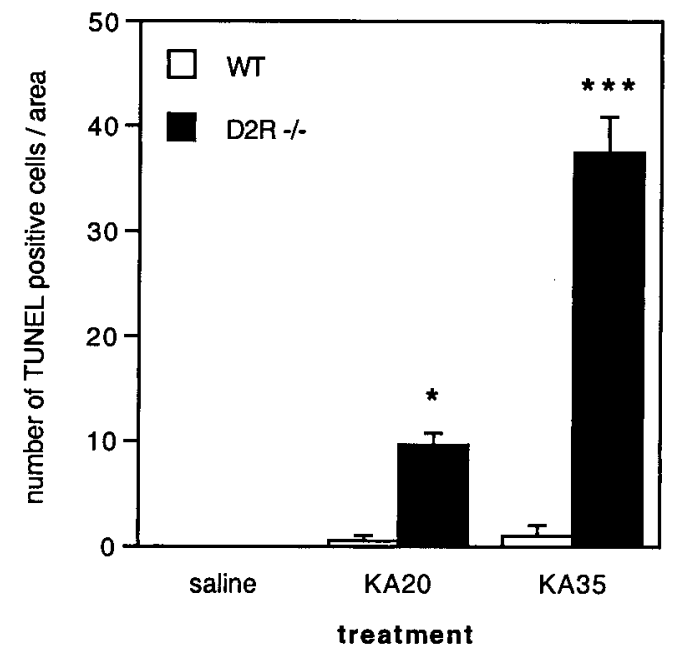

Figure 5. Quantification of TUNEL-positive hippocampal CA3 cells in WT and D2R $-/-$ mice treated with KA. Genotypes and treatments are as indicated. Values are expressed as the mean \pm SEM of TUNEL-positive CA3 cells per area, as described in Materials and Methods. ${ }^{*} p<0.05$, $\mathrm{D} 2 \mathrm{R}-/-20 \mathrm{mg} / \mathrm{kg} \mathrm{KA}(K A 20)$ treatment versus WT $K A 20$ and $\mathrm{D} 2 \mathrm{R}-/-$ saline; *** $p<0.0001, \mathrm{D} 2 \mathrm{R}-1-35 \mathrm{mg} / \mathrm{kg} \mathrm{KA}($ KA35) treatment versus WT $K A 35$ and D2R-/-KA20; Mann-Whitney $U$ test; $n=5$ animals per treatment group.

stained sections was also performed to evaluate the degree of CA3 hippocampal cell damage in the different genotypes and treatment groups. Table 1 shows the number of mice of each genotype and treatment that expressed none, little, mild, or severe cell damage (see Materials and Methods). The degree of CA3 cell damage (Table 1, Fig. $6 a, b$ ) in D2R $-/-$ mice treated with $35 \mathrm{mg} / \mathrm{kg}$ KA was higher than in $\mathrm{D} 2 \mathrm{R}-/-$ mice treated with $20 \mathrm{mg} / \mathrm{kg} \mathrm{KA}$, indicating a dose-dependent toxic effect. This was also confirmed by the higher number of TUNEL-positive cells (Figs. $4 a, b, 5)$ and by the larger extension of reactive gliosis (Fig. $6 c$ ) detected in D2R - / - mice treated with $35 \mathrm{mg} / \mathrm{kg}$ KA compared with D2R - / mice treated with $20 \mathrm{mg} / \mathrm{kg} \mathrm{KA}$. For each treatment, no difference in the degree of CA3 cell damage was observed between male and female mice of the same genotype. Saline-treated control animals of both genotypes revealed no histological abnormalities or gliosis in the hippocampus (data not shown).

Reults shown demonstrate that, despite seizure activity that was similar in WT and D2R - /- mice treated with $35 \mathrm{mg} / \mathrm{kg} \mathrm{KA}$ (Fig. 2 ), at this KA dose, hippocampal cell death was only observed in D2R $-/-$ mice. To investigate the relationship between IEG expression and hippocampal cell death, we therefore analyzed c-fos and c-jun mRNA induction in seizing WT and D2R-/- mice treated with $35 \mathrm{mg} / \mathrm{kg} \mathrm{KA}$. Three hours after KA administration, WT and D2R $-/-$ mice exhibited a comparable level of c-fos induction in the hippocampus, cerebral cortex, and subcortical areas (Fig. 7a). Conversely, a stronger c-jun induction was observed in the hippocampus and cerebral cortex of D2R $-/-$ mice $12 \mathrm{hr}$ after KA administration compared with WT animals (Fig. 7b). Thus, c-jun but not c-fos mRNA induction correlates with the occurrence of cell death in $\mathrm{D} 2 \mathrm{R}-/-$ mice.

KA-evoked seizures do not induce hippocampal cell damage in certain mouse strains (i.e., pure C57BL/6 or mixed $129 / \mathrm{Sv} \times$ C57BL/6) (Schauwecker and Steward, 1997). Thus, the absence of KA-induced brain damage (despite the presence of limbic seizures) (Fig. 2) in WT mice derived from the mixed $129 / \mathrm{Sv} \times$ 

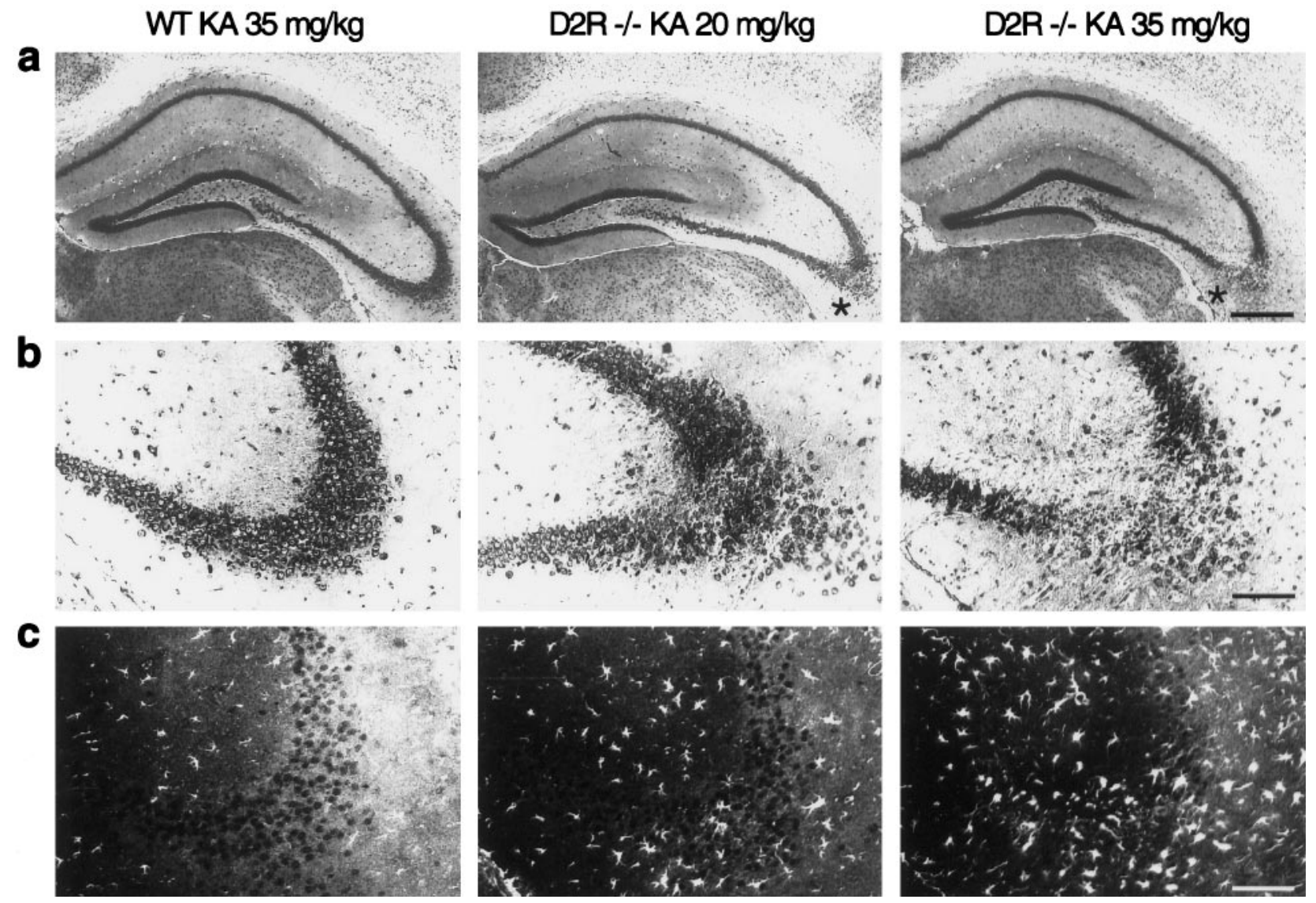

Figure 6. KA-evoked seizures induce CA3 cell damage in D2R-/- but not WT mice. $a$, Nissl staining of the whole dorsal hippocampus from mice killed $5 \mathrm{~d}$ after KA treatment. Asterisks indicate cell loss in a restricted part of the CA3 subfield in D2R $-/-$ mice. $b$, High-power magnifications taken from the same sections shown in $a$. $c$, GFAP immunostaining of the CA3 region. Genotypes and treatments are as indicated. Scale bars: $a, 270 \mu \mathrm{m} ; b, c, 70 \mu \mathrm{m}$.

Table 1. CA3 hippocampal cell damage in WT and D2R-/- kainatetreated mice

\begin{tabular}{lllll} 
& \multicolumn{4}{l}{$\begin{array}{l}\text { Degree of neuronal damage (num- } \\
\text { ber of animals) }\end{array}$} \\
\cline { 2 - 5 } Genotype/treatment & None & Little & Mild & Severe \\
\hline WT KA 35 mg/kg $(n=5)$ & 4 & 1 & 0 & 0 \\
D2R-/- KA 20 mg/kg $(n=5)$ & 0 & 0 & 4 & 1 \\
D2R-/- KA 35 mg/kg $(n=5)$ & 0 & 0 & 0 & 5
\end{tabular}

C57BL/6 genetic background (Figs. 4, 6) further supports our finding on a key role of D2R in the prevention of hippocampal cell death. However, to exclude a possible contribution of the 129/Sv genetic background to the observed effects (Silva et al., 1997), congenic C57BL/6 D2R-/- mice were also analyzed for their susceptibility to KA-induced excitotoxicity. In agreement with previous findings (Schauwecker and Steward, 1997), Nissl staining of brain sections from animals killed 5 d after KA treatment ( 20 or 35 $\mathrm{mg} / \mathrm{kg}$ ) did not reveal hippocampal cell damage in WT congenic C57BL/6 mice (Fig. 8a). Conversely, an extensive cell loss and tissue sclerosis in the CA3 region was observed in $\mathrm{D} 2 \mathrm{R}-/-$ mice of the same background (Fig. $8 b$ ).

\section{DISCUSSION}

The increased response of $\mathrm{D} 2 \mathrm{R}-/-$ mice to nonepileptogenic doses of KA demonstrates that the absence of D2R lowers the threshold for KA-induced limbic seizures. This suggests that dopamine, through $\mathrm{D} 2 \mathrm{R}$, exerts an inhibitory control on the response to seizure-promoting stimuli. The increased susceptibility to KA seizures showed by $\mathrm{D} 2 \mathrm{R}-/-$ is not attributable to a genetic back-

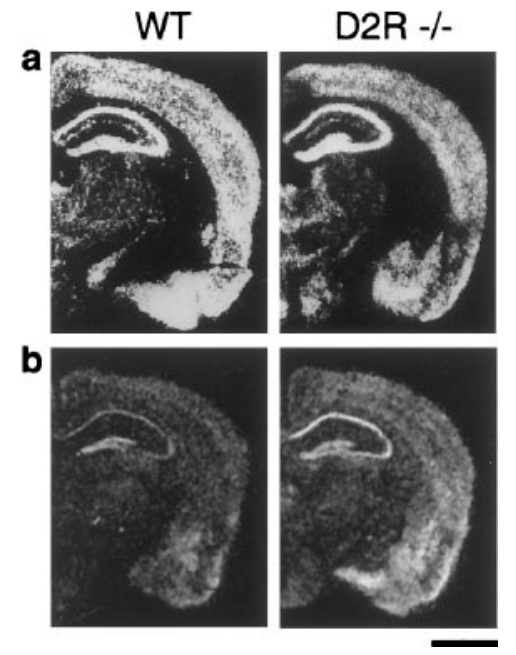

Figure 7. IEGs induction in the brain of $\mathrm{WT}$ and $\mathrm{D} 2 \mathrm{R}-/-$ mice treated with $35 \mathrm{mg} / \mathrm{kg} \mathrm{KA}$. c-fos $(a)$ and c-jun $(b)$ mRNA in situ hybridizations. Genotypes are as indicated. Scale bar, $1.2 \mathrm{~mm}$.

ground effect, because the two mouse strains from which $\mathrm{D} 2 \mathrm{R}-/-$ mice are derived (C57BL/6 and 129/Sv) showed the same KA dose-response profile as the WT derived from the $\mathrm{D} 2 \mathrm{R}-/-$ line. Interestingly, half dosage of $\mathrm{D} 2 \mathrm{R}$ in $\mathrm{D} 2 \mathrm{R}+/-$ mice is sufficient to provide the inhibitory control on limbic seizures because these animals showed no limbic seizures at $20 \mathrm{mg} / \mathrm{kg} \mathrm{KA}$.

The expression patterns of the immediate early genes c-fos and c-jun also correlate with the occurrence of limbic seizures in $\mathrm{D} 2 \mathrm{R}-/-$ mice. Our findings indicate that, in $\mathrm{D} 2 \mathrm{R}-/-$ mice, KA- 


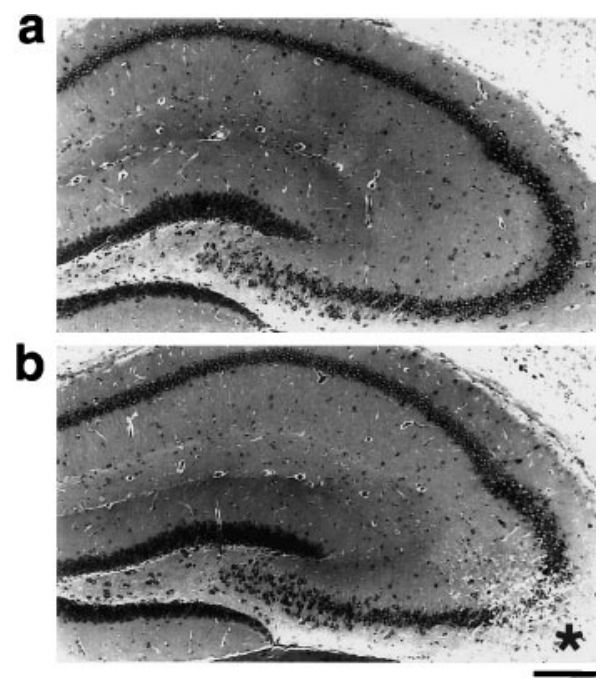

Figure 8. KA-evoked seizures induce CA3 cell damage in D2R-/- but not WT congenic C56BL/6 mice. Nissl staining of the whole dorsal hippocampus from WT $(a)$ and D2R $-/-(b)$ mice killed $5 \mathrm{~d}$ after $35 \mathrm{mg} / \mathrm{kg}$ KA treatment. Asterisks indicate cell loss in a restricted part of the CA3 subfield in D2R $-/-$ mice. Scale bar, $150 \mu \mathrm{m}$.

induced epileptic activity arises in the hippocampus and then spreads to other brain areas. Thus, a tonic D2R-mediated dopaminergic inhibitory control regulates the activation of limbic areas during seizures. Indeed, D2-sensitive seizure-regulating sites have been already identified in the hippocampus and other limbic areas (Starr, 1996). D2Rs, synthesized by pyramidal cells of CA1/CA3 fields and by granule cells of the dentate gyrus (Mansour et al., 1990), are mainly localized in the stratum lacunosum moleculare of the CA1/CA3 fields (Fig. 1a) (Martres et al., 1985), which contains the dendrites of pyramidal and granule cells (Amaral and Witter, 1995). D2Rs located on these cells could therefore contribute to the inhibition of hippocampal neuron excitability. Indeed, dopamine has markedly inhibitory effects on hippocampal pyramidal cells, as suggested by a series of electrophysiological studies (Stanzione et al., 1984; Pockett, 1985; Malenka and Nicoll, 1986; Otmakhova and Lisman, 1999). Increased excitatory glutamatergic neurotransmission in hippocampal neurons of $\mathrm{D} 2 \mathrm{R}-/-$ mice is not attributable to altered levels of glutamate receptors, because comparable levels of KA and AMPA receptors were found in the brain of WT and $\mathrm{D} 2 \mathrm{R}-/-$ mice (Fig. 1). A speculative hypothesis is that the absence of D2R might potentiate glutamatergic transmission by increasing the phosphorylation of glutamate receptors in the hippocampus. Indeed, glutamate receptor responses are potentiated via phosphorylation mechanisms (Wang et al., 1991; Roche et al., 1996), which are contributed to by dopamine receptor signaling (Hatt et al., 1995; Greengard et al., 1999; Yan et al., 1999).

A major finding of this study is that, in $\mathrm{D} 2 \mathrm{R}-/-$ mice, the stimulation of glutamate neurotransmission by KA results in extensive hippocampal cell death. Induction of c-jun mRNA and the proapoptotic factor BAX, as well as the presence of TUNELpositive cells, suggest that hippocampal cell death in KA-treated D2R - / - mice mainly occurs by apoptosis (Charriaut-Marlangue et al., 1996). The extension of BAX labeling and tissue damage in the CA3 subfield of $\mathrm{D} 2 \mathrm{R}-/-$ mice were larger than that of TUNEL staining (compare Figs. $4 c, 6 b$ with $4 b$ ), clearly indicating the progressive nature of apoptotic hippocampal cell death after KA-induced seizures (Ben-Ari, 1985; Charriaut-Marlangue et al., 1996). Cell loss in D2R-/- mice was present only in the CA3 subfield (Figs. 4, 6) but not in other regions of the hippocampus. It is well known that CA3 pyramidal neurons are the most vulnerable to the excitatory and neurotoxic effects of KA (Ben-Ari, 1985) because of the high density of KA binding sites in this region (Fig. 1b) (Berger and Ben-Ari, 1983).

Recent studies have shown that epileptogenic doses of KA induce hippocampal cell death only in some mouse strains (such as $129 / \mathrm{Sv}$ ) but not in others (such as C57BL/6 or $129 / \mathrm{Sv} \times \mathrm{C} 57 \mathrm{BL} / 6$ hybrids), whereas all of these strains exhibit the same susceptibility to KA-induced seizures (Schauwecker and Steward, 1997). It has been proposed previously (Schauwecker and Steward, 1997) that (1) the occurrence of KA-induced seizures in mice is not necessarily related to the occurrence of hippocampal cell death, and (2) the protection and susceptibility to KA-induced excitotoxicity are determined by specific gene(s) whose expression and/or function differs among different mouse strains. Our results suggest that the $\mathrm{D} 2 \mathrm{R}$ could be one of these genes. In fact, genetic ablation of D2R confers susceptibility to KA excitotoxicity in two mouse strains (mixed $129 / \mathrm{Sv} \times \mathrm{C} 57 \mathrm{BL} / 6$ or congenic C57BL/6) that are known to be resistant to KA-induced neurodegeneration.

We reported previously that D2R ablation causes hormonal dysfunctions (Saiardi et al., 1997), mainly in female animals. It is well known from a large series of studies that steroid hormones can influence seizure threshold and seizure-related brain damage (Joels, 1997; Green and Simpkins, 2000). However, in the present study, we could not find evidence of difference between genders. This suggests that, at least in our experimental model, hormonal alterations are not crucially involved in the regulation of seizures and seizure-related cell death.

To our knowledge, our data constitute the first in vivo demonstration of a direct role of D2R signaling in the control of epilepsyrelated brain damage. We speculate that dopamine signaling, through D2R, modulates the susceptibility of hippocampal neurons to enter apoptotic cell death pathways. In this respect, it has been proposed that dopamine D2 receptors can exert a protective role against glutamate-induced neurotoxicity in vitro (Amano et al., 1994; Sawada et al., 1998). Glutamate toxicity has also been implicated in cerebral ischemia and Parkinson's disease (Meldrum, 1995; Blandini et al., 1996; Lange et al., 1997). In vivo, dopamine D2-selective agonists can protect hippocampal neurons against degeneration after cerebral ischemia (O’Neill et al., 1998). Moreover, several authors have postulated a neuroprotective role of dopamine D2 receptors in different animal models of parkinsonism (Olanow et al., 1998). Indeed, the D2-selective agonist bromocriptine is able to protect nigral neurons against 1-methyl-4-phenyl1,2,3,6-tetrahydropyridine-induced neurodegeneration (Lange et al., 1994; Muralikrishnan and Mohanakumar, 1998).

A large series of experimental and clinical studies strongly suggest that dopamine, through D2 receptors, can exert an antiepileptic action (Starr, 1996). Interestingly, KA-induced seizures in rodents are generally considered as a good model of human temporal lobe epilepsy (TLE) (Ben-Ari, 1985). Indeed, TLE can be successfully treated with the administration of D2-like selective agonists and is also associated, at least in certain cases, to pituitary tumors (Clemens, 1988; Gatterau et al., 1990) that resemble those exhibited by D2R-/- mice (Saiardi et al., 1997). Together with these findings, our data suggest that TLE might be attributable to a reduced expression or function of dopamine D2 receptors. Our results also support the notion that dopamine, through D2Rs, can exert a protective role against neuropathologies that involve glutamate-induced neurodegeneration, including epilepsy, ischemia, schizophrenia (Csernansky and Bardgett, 1998), and Parkinson's disease.

\section{REFERENCES}

Amano T, Ujihara H, Matsubayashi H, Sasa M, Yokota T, Tamura Y, Akaike A (1994) Dopamine-induced protection of striatal neurons against kainate receptor-mediated glutamate cytotoxicity in vitro. Brain Res 655:61-69.

Amaral DG, Witter MP (1995) Hippocampal formation. In: The rat nervous system (Paxinos G, ed), pp 215-237. San Diego: Academic.

Baik JH, Picetti R, Saiardi A, Thiriet G, Dierich A, Depaulis A, Le Meur M, Borrelli E (1995) Parkinsonian-like locomotor impairment in mice lacking dopamine D2 receptors. Nature 377:424-428.

Ben-Ari Y (1985) Limbic seizures and brain damage produced by kainic acid: mechanisms and relevance to human temporal lobe epilepsy. Neuroscience 14:375-403.

Berger M, Ben-Ari Y (1983) Autoradiographic visualization of $\left[{ }^{3} \mathrm{H}\right]$ kainic acid receptor subtypes in the rat hippocampus. Neurosci Lett 39:237-242. 
Blandini F, Porter RH, Greenamyre JT (1996) Glutamate and Parkinson's disease. Mol Neurobiol 12:73-94.

Bouthenet ML, Martres MP, Sales N, Schwartz JC (1987) A detailed mapping of dopamine D-2 receptors in rat central nervous system by autoradiography with [ $\left.{ }^{125} \mathrm{I}\right]$ iodosulpride. Neuroscience 20:117-155.

Bouthenet ML, Souil E, Martres MP, Sokoloff P, Giros B, Schwartz JC (1991) Localization of dopamine D3 receptor mRNA in the rat brain using in situ hybridization histochemistry: comparison with dopamine D2 receptor mRNA. Brain Res 564:203-219.

Bozzi Y, Borrelli E (1999) Absence of the dopamine D2 receptor leads to a decreased expression of GDNF and NT-4 mRNAs in restricted brain areas. Eur J Neurosci 11:1275-1284.

Charriaut-Marlangue C, Aggoun-Zouaoui D, Represa A, Ben-Ari Y (1996) Apoptotic features of selective neuronal death in ischemia, epilepsy and gp120 toxicity. Trends Neurosci 19:109-114.

Choi DW (1988) Glutamate neurotoxicity and diseases of the nervous system. Neuron 1:623-634.

Choi DW (1994) Glutamate receptors and the induction of excitotoxic neuronal death. Prog Brain Res 100:47-51.

Clemens B (1988) Dopamine agonist treatment of self-induced patternsensitive epilepsy. A case report. Epilepsy Res 2:340-343.

Coyle JT, Puttfarcken P (1993) Oxidative stress, glutamate, and neurodegenerative disorders. Science 262:689-695.

Csernansky JG, Bardgett ME (1998) Limbic-cortical neuronal damage and the pathophysiology of schizophrenia. Schizophr Bull 24:231-248.

Deckwerth TL, Elliott JL, Knudson CM, Johnson Jr EM, Snider WD, Korsmeyer SJ (1996) BAX is required for neuronal death after trophic factor deprivation and during development. Neuron 17:401-411.

Dingledine R, McBain CJ, McNamara OJ (1990) Excitatory amino acids and epilepsy. Trends Pharmacol Sci 11:334-338.

Dusart I, Marty S, Peschanski M (1991) Glial changes after an excitotoxic lesion in the CNS. II. Astrocytes. Neuroscience 45:541-549.

Estus S, Zaks WJ, Freeman RS, Gruda M, Bravo R, Johnson EMJr (1994) Altered gene expression during programmed cell death: identification of c-jun as necessary for neuronal apoptosis. J Cell Biol 127:1717-1727.

Franklin KBJ, Paxinos G (1997) The mouse brain in stereotaxic coordinates. San Diego: Academic.

Gatterau A, Vezina J, Rousseau S, Bielmann P (1990) Hyperprolactinaemia and temporal lobe epilepsy in a woman: concomitant and persistent prolactin suppression and temporal lobe epilepsy relief. J Endocrinol Invest 13:247-249.

Gillardon F, Wickert H, Zimmermann M (1995) Up-regulation of bax and down-regulation of bcl-2 is associated with kainate-induced apoptosis in mouse brain. Neurosci Lett 195:85-88.

Green PS, Simpkins JW (2000) Neuroprotective effects of estrogens: potential mechanisms of action. Int J Dev Neurosci 18:347-358.

Greengard P, Allen PB, Nairn AC (1999) Beyond the dopamine receptor: the DARPP-32/Protein Phosphatase-1 cascade. Neuron 23:435-447.

Halazonetis TD, Georgopoulos K, Greenberg ME, Leder P (1988) c-Jun dimerizes with itself and with c-Fos, forming complexes of different DNA binding activities. Cell 55:917-924.

Hatt H, Schmidt KF, Smith DO (1995) Dopaminergic modulation of glutamate-activated channels in the central nervous system. J Neural Transm Suppl 46:77-86.

Hollmann M, Heinemann S (1994) Cloned glutamate receptors. Annu Rev Neurosci 17:31-108.

Jackson DM, Westlind-Danielsson A (1994) Dopamine receptors: molecular biology, biochemistry and behavioral aspects. Pharmacol Ther 64:291-370.

Joels M (1997) Steroid hormones and excitability in the mammalian brain. Front Neuroendocrinol 18:2-48.

Krajewski S, Mai JK, Krajewska M, Sikorska M, Mossakowski MJ, Reed JC (1995) Upregulation of bax protein levels in neurons following cerebral ischemia. J Neurosci 15:6364-6376.

Lange KW, Rausch WD, Gsell W, Naumann M, Oestreicher E, Riederer P (1994) Neuroprotection by dopamine agonists. J Neural Transm Suppl 43:183-201.

Lange KW, Kornhuber J, Riederer P (1997) Dopamine/glutamate interactions in Parkinson's disease. Neurosci Biobehav Rev 21:393-400.

Lothman EW, Collins RC (1981) Kainic acid induced limbic seizures: metabolical, behavioral, electroencephalographic and neuropathological correlates. Brain Res 218:299-318.

Lothman EW, Collins RC, Ferrendelli JA (1981) Kainic acid-induced limbic seizures: electrophysiologic studies. Neurology 31:806-812.

Malenka RC, Nicoll RA (1986) Dopamine decreases the calciumactivated afterhyperpolarization in hippocampal CA1 pyramidal neurons. Brain Res 379:210-215.

Mansour A, Meador-Woodruff JH, Bunzow JR, Civelli O, Akil H, Watson
SJ (1990) Localization of dopamine D2 receptor mRNA and D1 and D2 receptor binding in the rat brain and pituitary: an in situ hybridizationreceptor autoradiographic analysis. J Neurosci 10:2587-2600.

Martres MP, Bouthenet ML, Sales N, Sokoloff P, Schwartz JC (1985) Widespread distribution of brain dopamine receptors evidenced with $\left[{ }^{125} \mathrm{I}\right]$ Iodosulpride, a highly selective ligand. Science 228:752-755.

Meldrum BS (1995) Excitatory amino acid receptors and their role in epilepsy and cerebral ischemia. Ann NY Acad Sci 757:492-505.

Mellström B, Achaval M, Montero D, Naranjo JR, Sassone-Corsi P (1991) Differential expression of the jun family members in rat brain. Oncogene 6:1959-1964.

Morgan JI, Curran T (1991) Proto-oncogene transcription factors and epilepsy. Trends Pharmacol Sci 12:343-349.

Morrison RS, Wenzel HJ, Kinoshita Y, Robbins CA, Donehower LA, Schwartzkroin PA (1996) Loss of the p53 tumor suppressor gene protects neurons from kainate-induced cell death. J Neurosci 16:1337-1345.

Muralikrishnan D, Mohanakumar KP (1998) Neuroprotection by bromocriptine against 1-methyl-4-phenyl-1,2,3,6-tetrahydropyridine-induced neurotoxicity in mice. FASEB J 12:905-912.

Olanow CW, Jenner P, Brooks D (1998) Dopamine agonists and neuroprotection in Parkinson's disease. Ann Neurol 44:S167-S174.

O'Neill MJ, Hicks CA, Ward MA, Cardwell GP, Reymann JM, Allain H, Bentue-Ferrer D (1998) Dopamine D2 receptor agonists protect against ischaemia-induced hippocampal neurodegeneration in global cerebral ischaemia. Eur J Pharmacol 352:37-46.

Otmakhova NA, Lisman JE (1999) Dopamine selectively inhibits the direct cortical pathway to the CA1 hippocampal region. J Neurosci 19:1437-1445

Pockett S (1985) Dopamine changes the shape of action potentials in hippocampal pyramidal cells. Brain Res 342:386-390.

Pollard H, Charriaut-Marlangue C, Cantagrel S, Represa A, Robain O, Moreau J, Ben-Ari Y (1994) Kainate-induced apoptotic cell death in hippocampal neurons. Neuroscience 63:7-18.

Roche KW, O’Brien RJ, Mammen AL, Bernhardt J, Huganir RL (1996) Characterization of multiple phosphorylation sites on the AMPA receptor GluR1 subunit. Neuron 16:1179-1188.

Saiardi A, Bozzi Y, Baik JH, Borrelli E (1997) Antiproliferative role of dopamine: loss of D2 receptors causes hormonal dysfunction and pituitary hyperplasia. Neuron 19:115-126.

Sakhi S, Bruce A, Sun N, Tocco G, Baudry M, Schreiber SS (1994) p53 induction is associated with neuronal damage in the central nervous system. Proc Natl Acad Sci USA 91:7525-7529.

Sawada H, Ibi M, Kihara T, Urushitani M, Akaike A, Kimura J, Shimohama S (1998) Dopamine D2-type agonists protect mesencephalic neurons from glutamate neurotoxicity: mechanisms of neuroprotective treatment against oxidative stress. Ann Neurol 44:110-119.

Schauwecker PE, Steward O (1997) Genetic determinants of susceptibility to cytotoxic cell death: implications for gene targeting approaches. Proc Natl Acad Sci USA 94:4103-4108.

Seeburg PH (1993) The molecular biology of mammalian glutamate receptor channels. Trends Neurosci 14:297-303.

Silva AJ, Simpson EM, Takahashi JS, Lipp HP, Nakanishi S, Wehner JM, Giese KP, Tully T, Abel T, Chapman PF, Fox K, Grant S, Itohara S, Lathe R, Mayford M, McNamara JO, Morris RJ, Picciotto M, Roder J, Shin HS, Slesinger PA, Storm DR, Stryker MP, Tonegawa S, Wang Y, Wolfer DP (1997) Mutant mice and neuroscience: recommendations concerning genetic background. Neuron 19:755-759.

Stanzione P, Calabresi P, Mercuri N, Bernardi G (1984) Dopamine modulates CA1 hippocampal neurons by elevating the threshold for spike generation: an in vitro study. J Neurosci 13:1105-1116.

Starr MS (1993) Regulation of seizure threshold by D1 versus D2 receptors. In: D1/D2 dopamine receptor interactions (Waddington J, ed), pp 235-269. New York: Academic.

Starr MS (1996) The role of dopamine in epilepsy. Synapse 22:159-194.

Verney C, Baulac M, Berger B, Alvarez C, Vigny A, Helle KB (1985) Morphological evidence for a dopaminergic terminal field in the hippocampal formation of young and adult rat. Neuroscience 14:1039-1052.

Wang LY, Salter MW, MacDonald JF (1991) Regulation of kainate receptor by cAMP-dependent protein kinase and phosphatases. Science 253:1132-1138.

Willoughby JO, Mackenzie L, Medvedev A, Hiscock JJ (1997) Fos induction following systemic kainic acid: early expression in the hippocampus and later widespread expression correlated with seizure. Neuroscience 77:379-392.

Yan Z, Hsieh-Wilson L, Feng J, Tomizawa K, Allen PB, Fienberg AA, Nairn AC, Greengard P (1999) Protein phosphatase 1 modulation of neostriatal AMPA channels: regulation by DARPP-32 and spinophilin. Nat Neurosci 2:13-17. 